\title{
SOFT POWER ROSJI
}

Celem artykułu jest określenie miękkiej siły Rosji, którą państwo wykorzystuje dla wzrostu swej potęgi. Zadanie to nie jest łatwe, tym bardziej, że nawet próba określenia czym jest potęga i siła, może przynieść szereg wątpliwości. Na potrzeby artykułu należy przyjąć, że potęga jest hipotetyczną zdolnością państwa do użycia swych materialnych i pozamaterialnych zasobów w celu wykonania własnej woli bez względu na sprzeciw lub współdziałanie innych uczestników (Kleinowski, 2010: 52). Siła jest związana z użyciem przez państwo zmobilizowanych w określonych warunkach zasobów materialnych i pozamaterialnych w celu wykonania własnej woli bez względu na sprzeciw lub współdziałanie innych jej uczestników (Moczulski, 1999: 402; Sułek, 2001: 57). Siła jest więc działaniem lub wpływem a nie hipotetyczną możliwością, a jej wielkość zależy od przydatności w danym czasie i miejscu.

Samo soft power jest pojęciem, które w sensie badawczym jest zjawiskiem stosunkowo młodym, ale miękka siła stosowana jest w relacjach międzynarodowych od zawsze. Pojęcie soft power zostało dostrzeżone przez Josepha Nye’a, Jr., który użył tego sformułowania w książce Bound to Lead: the Changing Nature of American Power (Nye, 1991). Następnie, wykorzystał ten koncept w kolejnych publikacjach (Nye, 2002; 2005; 2007; 2011). J. Nye wprowadzając pojęcie soft power do terminologii stosunków międzynarodowych określił je jako zdolność kształtowania preferencji innych dzięki atrakcyjności i przyciaganiu za pomocą posiadanych zasobów, do których zaliczył kulturę, wartości i styl uprawiania polityki zagranicznej.

Zwolennicy soft power obwarowali jednak zarówno samo pojęcie, jak i granice jego stosowalności wieloma zastrzeżeniami, co świadczyło o trudnościach z określeniem uniwersalnych zasad, metod i weryfikowalnych wyników badań (Nye, 2006: 23-37). W Rosji pojęcie soft power tłumaczy się najczęściej jako miękka siła, władza, potęga, bądź elastyczna siła (Dolinsky, 2012: 16).

\section{STRATEGIA POLITYKI ZAGRANICZNEJ FEDERACJI ROSYJSKIEJ}

Po rozpadzie ZSRR, Rosja jako jej sukcesor, mimo wysiłków straciła pozycję supermocarstwa i tym samym stała się przedmiotem rozgrywek sił zewnętrznych, ulegając interesom innych (Krasuski, 2007: 41; Matuszewska, 2010: 213), tracąc przy tym wiele z poczucia wyjątkowości w polityce światowej (Nye, 2011: 170). W swej polityce Rosja zakwestionowała obowiązujący wzorzec przechodzenia od komunizmu

${ }^{1}$ Artykuł powstał w ramach grantu NCN UMO - 2011/01/B/HS5/00678 Soft power we współczesnych stosunkach międzynarodowych. 
do kapitalizmu i wybrała własną ścieżkę rozwoju. W przypadku Rosji ceną za ten wybór jest porównywanie z ChRL, co sprawia, że nie tylko rządzący mieli poczucie napiętnowania ze strony Zachodu wynikające z pozostawania po „złej”, autorytarnej stronie, odwołując się często do instrumentów hard power (Krasuski, 2007; 20). Sami Rosjanie widzieli się raczej jako ofiarę zmian ładu międzynarodowego, postrzeganą powierzchownie przez komunizm, KGB, mafie, korupcję, zabójstwo dziennikarzy, procesy polityczne, konflikt z sąsiadami, co mocno wpływa na negatywną ocenę tego państwa (Evans, 2005: 127).

Początkowo polityka Federacji Rosyjskiej, rządzonej przez Borysa Jelcyna, była proeuropejska (Włodkowska, 2004: 82). Zmiana polityczna nastapiła szybko, a druga kadencja wprowadziła zdecydowane zmiany, związane również z rozszerzeniem NATO na wschód. Okres lat 1997-2000 to początek ery Władimira Putina, który już jako premier zatwierdził nową koncepcję polityki zagranicznej (2000 r.). Okresem przejściowym był 2001 r., co było związane z zamachem z 11 września. W okresie tym doszło do wyraźnego porozumienia z USA i innymi krajami zachodu. Okazało się, że Rosja jest potrzebna do kontrolowania Iranu, Bliskiego Wschodu, Afganistanu i Korei Północnej. Kontakty pogorszyły się na przełomie 2003-2004, w okresie wojny w Iraku, a w późniejszych latach konflikt zaostrzył się w związku z agresją na Gruzję i na Ukrainie.

Po objęciu w lipcu 2008 r. przez Dmitrija Miedwiediewa funkcji prezydenta, zatwierdzono koncepcje polityki zagranicznej Federacji Rosyjskiej (2009). Uznano w niej, że najważniejsze jest zapewnienie bezpieczeństwa i umocnienie suwerenności oraz integralności terytorialnej. Uznano wówczas, że jednym z zagrożeń dla Rosji jest rozszerzenie NATO o Ukrainę i Gruzję (Pastukhov, 2010; Potocki, 2009: 280). W dalszej kolejności należało stworzyć zewnętrznie korzystne warunki dla rozwoju Rosji: oddziaływanie na procesy zewnętrzne w celu stworzenia porządku opartego na sprawiedliwości i kolektywnym rozwiązywaniu problemów, pierwszeństwie prawa międzynarodowego w tym pośrednictwie ONZ. Tworzenie dobrosąsiedzkich stosunków, likwidacja zagrożeń; wszechstronna obrona granic; współdziałanie na rzecz obiektywnego postrzegania Rosji w świecie jako państwa demokratycznego, z socjalnie ukierunkowaną gospodarką rynkową i niezależną polityką zagraniczną; poparcie i popularyzacja w innych krajach języka rosyjskiego i kultury narodów Rosji, które wnoszą unikatowy wkład w kulturową-cywilizacyjną różnorodność współczesnego świata i rozwój partnerstwa cywilizacji (Czajkowski, 2011: 80). Wśród tych propozycji w tej koncepcji widać wyraźnie odwołanie do soft power, której narzędzia mogłyby wzmocnić pozycję Federacji Rosyjskiej.

W lutym 2013 r. nowa Koncepcja polityki zagranicznej Federacji Rosyjskiej podkreśliła poprzednie założenia, podkreślając konieczność kooperacji międzynarodowej i podwyższenia pozycji Rosji w świecie przez aktywizację dyplomacji publicznej, cyfrowej, nauki i kultury (Concept, 2013). Wspomniano również o wykorzystywaniu miękkiej siły na rzecz realizacji rosyjskich interesów ${ }^{2}$, zwracając szczególną uwagę na konieczność rozwoju środków, dzięki którym można będzie wpływać na opinię

${ }^{2}$ Witold Rodkiewicz zauważa, że „(r)osyjskie rozumienie „miękkiej siły” jest osadzone w lokalnej tradycji politycznej i polega na zdolności do aktywnego wpływania na kształtowanie opinii o Rosji w zagranicznych środowiskach opiniotwórczych i do manipulowania zagraniczną opinią publiczną przy pomocy formalnie niezależnych od państwa instytucji i środowisk". Patrz: Rodkiewicz, 2013. 
publiczną za granicą. Zadeklarowano konieczność wykorzystania mediów w ramach rosyjskiej dyplomacji publicznej. Wszystko to miało przyczynić się do „obiektywnego postrzegania Rosji na świecie", uzyskania zrozumienia i poparcia dla jej polityki (Lukyanov, 2013; Nye, 2013).

Niemniej ta forma wykorzystania narzędzi soft power jest ograniczona przez niedemokratyczny charakter władzy w Rosji, raczej nieprzyjazne postrzeganie środowiska zewnętrznego (syndrom „oblężonej twierdzy”) i odseparowania elit od społeczeństwa. Utrudnia to, czy nawet uniemożliwia obywatelom wgląd w pracę instytucji państwowych i wpływ na procesy decyzyjne, a także ogranicza personalizację kont i prowadzenie dyskusji w serwisach społecznościowych.

Na niekorzyść Rosji przemawia nazbyt silne szafowanie siłą, co utrudniało Federacji Rosyjskiej realizację jej głównego celu, tj. skupienia byłych republik radzieckich wokół siebie. Polityka zagraniczna Federacji Rosyjskiej wykorzystuje z powodzeniem narzędzia ekonomiczne i militarne, co ukazuje jej twarde oblicze zgodnie z naturą tych metod. W aspekcie użycia sił zbrojnych Rosja sięga po nią często, nawet wówczas, gdy możliwe jest użycie innych narzędzi oddziaływania. Rosja, która dysponuje znaczną siłą militarna, może budzić respekt, ale nie jest w stanie zyskać uznania środowiska międzynarodowego. Ponadto rządzący w Rosji nie byli w stanie kalibrować akcji, które w zamiarze miały przynieść podniesienie jej wizerunku w świecie (Lucas, 2008).

W sferze polityki ekonomicznej Rosji trudno było wykorzystać te elementy, które w rezultacie mogą tworzyć miękkie wpływy, decydując się na jej twardą wersję. Nie bez znaczenia jest posiadanie surowców energetycznych, które są kartą przetargową dla osiaggania celów politycznych (Stulberg, 2007; Lucas, 2008). Rozwój ekonomiczny dla Rosji jest niezwykle ważny również i dlatego, że przyczynia się do tworzenia dobrobytu, co z kolei może jej pomóc we wzmocnieniu atrakcyjności jako państwa, które odniosło sukces. Rosyjska gospodarka z pewnością jest najpotężniejsza w skali regionu, posiada wiele ważnych i znanych na obszarze WNP i poza nim firm, a dobrze rozwinięty przemysł przyciagga imigrantów ${ }^{3}$. Coraz więcej mieszkańców państw WNP przyjeżdża do Moskwy czy Sankt Petersburga, szukając bardziej kolorowego i światowego życia.

Ekonomizacja polityki rosyjskiej jest dostrzegalna również w zaangażowaniu na rzecz integracji w sferze gospodarczej (Podliesnyj, 2004: 205). W październiku 2000 r. Rosja, Kazachstan, Kirgistan i Tadżykistan przekształciły stworzoną przez nie unię celną w Eurazjatyckie Stowarzyszenie Gospodarcze (ESG). W październiku 2004 r. Rosja przystapiła do powstałej jedenaście lat wcześniej Środkowoazjatyckiej Wspólnoty Gospodarczej, której nazwa została zmieniona w 2002 r. na Środkowoazjatycką Organizację Współpracy. W maju 2004 r., Rosja dołączyła również do utworzonego w 1998 r. Stowarzyszenia Środkowoazjatyckiego, skupiającego Kazachstan, Kirgistan, Uzbekistan i Tadżykistan. Rosja stara się wiązać kraje układami zależności, tworząc sieć współpracy, dążąc do wykorzystania jej jako alternatywy wobec struktur zachodnich.

Słabością polityki zagranicznej Federacji Rosyjskiej był praktycznie brak możliwości konstruowania nowego porządku oraz umiejętność systemu do zmiany wpły-

${ }^{3}$ Wśród firm: Gazprom, Lukoil, Rosnieft (sektor paliwowy), Sievierstal (hutnictwo), NorylskijNikel (metalurgia), MTS (telekomunikacja), AFK Sistema (holding). 
wów. Było to o tyle ważne, że początek XXI w. zaskoczył władze Rosji tzw. „kolorowymi rewolucjami”, które zachwiały jej pozycją w regionie WNP. Szczególnie rewolucja ukraińska z 2004 r., a później Euro-majdan, postawił rosyjskich decydentów przed koniecznością wprowadzenia zmian. Ponadto proces integracji europejskiej, niezależnie od wewnętrznej i zewnętrznej krytyki, stanowi dla Rosji duże wyzwanie. Rosja ma w integrującej się Europie poważnego konkurenta, zwłaszcza jeśli chodzi o postsowieckich sąsiadów Unii Europejskiej, którzy deklarują wolę przystąpienia do instytucji i mechanizmów kierowanych z Brukseli, chcąc uzyskać wsparcie dla budowy swoich narodowych organizmów. Dla Rosji stosunki z UE wobec jej aktywności na obszarze postradzieckim stanowiło zagrożenie. Tu jedyną rolę, jeżeli chciało się uniknąć ostracyzmu, mogły odegrać narzędzia soft power.

W tej sytuacji dla Rosji ważne jest odnalezienie się w nowym ładzie międzynarodowym. Istotne dla niej było i jest, aby poszukać alternatywy wobec Zachodu w Azji. Rosja nie pozostawiła $w$ ten sposób sobie manewru i wydawało się, że nie ma innej alternatywy jak szukać porozumienia z ChRL. Skala zbliżenia była na tyle duża, że wzajemne relacje w 1996 r., nazwano „strategicznym partnerstwem”. Kilka lat później, w 2001 r. podpisano układ o przyjaźni i kooperacji. Tłem dla tego partnerstwa jest powszechna opozycja do współczesnego - zdominowanego przez USA - świata (Nye, 2011: 171). Sojusz ten nazwano filarami porozumienia www (ang. World Without the West), który można w pełni osiagnąć z wykorzystaniem możliwości soft power. Trudno dyskutować z optymalizacją polityki Kremla. Rosja i ChRL mają rozbieżne spojrzenie na świat, inne podejście do polityki zagranicznej, a czasem konfliktowe priorytety. Niemniej to ChRL chcąc sięgnąc po światowy prymat, zainteresowana jest dobrymi stosunkami z Rosją.

\section{KULTURA I WARTOŚCI JAKO ZASÓB SOFT POWER}

Dyskusja o kulturze Rosji dotyczy problemów skupionych wokół haseł „Rosja - dusza świata" i Moskwa - Trzeci Rzym, co powoduje, że Rosja może mieć trudności adaptacyjne do współczesnego świata (Broda, 2011: 212). Podkreśla się chętnie zagadnienia niepoznawalności rosyjskiej duszy, co prowadzi do tworzenia stereotypów, od których trudno się Rosjanom uwolnić. Dlatego Rosjanie są przekonani o ocenie przez innych w wymiarze negatywnych stereotypów, tradycyjnych wyobrażen, determinacji historii, przekonania o odmienności rosyjskiego losu. W dużej części ta odmienność wynika z przekonania, że Rosja to kultura zamknięta i zainteresowanie nią ma wyraźnie określoną grupę odbiorców (Lazari, 1996: 86). W patriotycznych publikacjach przewija się duch odrzucenia zachodnich rozwiązań cywilizacyjnych jako niezgodnych z rosyjską naturą. W tym kontekście Zachód jest odwiecznym wrogiem Rosji, dążącym do zbudowania jednej cywilizacji światowej oraz pragnącym unicestwić Moskwę w imię światowego porządku (Wyciszkiewicz, 2003: 45).

Lata współistnienia w jednym państwie, jakim było Imperium Rosyjskie i ZSRR, w sposób naturalny wytworzyły wspólnotę historyczną oraz więzy językowe. W tym sensie elementem korzystnym jest liczna diaspora oraz wspólnota językowa (Sherr, 2013: 90). Trudno jednoznacznie określić związek pomiędzy pochodzeniem a języ- 
kiem. Z przyczyn historycznych, wybór języka stanowi bardziej kwestie zamieszkiwanego regionu niż pochodzenia. Oba te czynniki wskazują iż język nie jest decydującym wyznacznikiem jeśli chodzi o orientację polityczną oraz lojalność. Po ponad 20 latach od ogłoszenia niepodległości granice językowe pomiędzy społecznościami zostały zmienione, ale krąg ludzi posługujących się językiem lokalnym rozszerza się. Niemniej język rosyjski ma nadal szansę stać się lingua franca obszaru WNP, co może pomóc Federacji Rosyjskiej w szerzeniu kultury, tradycji czy wartości. W promocji mowy rosyjskiej Rosja wspiera się również na licznej ludności rosyjskiej i rosyjskojęzycznej, zamieszkującej byłe republiki radzieckie. Stanowią one naturalny nośnik rosyjskich wartości, tradycji, obyczajów i języka. Jednak widoczny jest stopniowy spadek zainteresowania tym językiem, w szczególności w państwach należących, bądź aspirujących do członkostwa w Unii Europejskiej.

Kultura rosyjska jest szeroko znana i szanowana na całym świecie oraz w przeciwieństwie do amerykańskiej często kojarzona z kulturą wysoką. Kultura rosyjska jest w dużym stopniu wypadkową kultur poszczególnych narodów, zamieszkujących przez wieki terytorium tego ogromnego państwa, których twórczość przez dziesięciolecia była traktowana jako radziecka. Nazwiska twórców znanych utworów literackich to kanon literatury światowej (Lew Tołstoj, Aleksander Puszkin, Fiodor Dostojewski, Mikołaj Gogol, Michał Bułhakow), muzyki (Piotr Czajkowski, Siergiej Rachmaninow, Igor Stawiński, Dymitr Szostakowicz). Cenione są rosyjskie muzea czy ludzie nauki (Dmitrij Mendelejew, Siergiej Korolow).

Innym elementem wpływu na rozwój soft power są wartości, wśród których najważniejsze są te, dzięki którym Rosja mogłaby odróżnić się od Zachodu. W latach dziewięćdziesiątych XX w. w Rosji rozważano przyjęcie alternatywnego modelu polityczno-ekonomicznego w stosunku do liberalnego i demokratycznego Zachodu. Wartości polityczne, takie jak demokracja czy prawa człowieka, mogą być silnym źródłem przyciagania dla Rosji, ale nie wystarczą deklaracje o wartościach, ale ich stosowanie i przestrzeganie. Rosja nie może w tych kategoriach sprostać konkurencji z Zachodem, co jest tym istotniejsze, że aktywność państw zachodnich, przyciaga i przekonuje wiele państw. Ideologia Zachodu część z nich przekonuje, tym bardziej, że tej ideologii brakowało w Rosji. Mając świadomość pustki ideologicznej rosyjscy decydenci wypełnili ją koncepcją suwerennej demokracji, odmiennej od tej proponowanej na Zachodzie.

Rosja odrzuciła model, który zakładałby konieczność przyswojenia nie zawsze wygodnych zachodnich wartości postrzeganych jako potencjalne zagrożenie. Było to tym silniejsze, że Rosja wyraźnie preferuje rozwiązania siłowe i w sytuacjach spornych, gotowa jest tak rozwiązywać konflikty. Tak było w przypadku konfliktów na Kaukazie (Czechenia i Gruzja) oraz na Ukrainie (Potocki 2009; Miszewski, 2012: 494-501).

Rosja ma trudności w kształtowaniu się wartości. Obok tych związanych z ideą III Rzymu i prawosławiem, ma jednak przeszkody systemowe, aby rozwinąc soft power. Dla społeczeństwa rosyjskiego widać było, że po Jelcynie potrzebny jest silny przywódca, który ustabilizuje państwo. W. Putin okazał się człowiekiem pasującym do rzeczywistości (Lucas, 2008: 262), który zamiast demokratyzacji kojarzącej się z chaosem, brakami i niepewnością, zaproponował system oparty na innych wartościach (Averinos, 2009). 
Niezależnie od nowej rosyjskiej koncepcji suwerennej demokracji, w kręgach naukowych i artystycznych wciąż powraca dziewiętnastowieczna idea eurazjatyzmu. Jej stronnicy są zwolennikami „,multipolarnego” ładu świata, w którym wielość ośrodków siły zapewni, ich zdaniem, równowagę i zwiększy bezpieczeństwo. Taki porządek daje również szansę odegrania przez Rosję roli lidera jednego z biegunów wpływów. Zdaniem eurazjatystów właśnie to wyjątkowe położenie geopolityczne Rosji na masywie eurazjatyckim pozwala jej łączyć dwa światy i dwie cywilizacje (Gumilov, 1996). Ta specyfika i odcięcie (również historyczne) od cywilizacji zachodniej, zdaniem euroazjatystów, przesądza o wyborze alternatywy w rozwoju państwa rosyjskiego, określanej mianem trzeciej drogi.

\section{INSTRUMENTY SOFT POWER}

Należy przyjąć, że Rosja ma kłopoty z wykorzystaniem soft power, nawet jeżeli były ku temu stosowne zasoby. Niekiedy rozwiązania siłowe czy budowane na strachu relacje wydają się szybsze do osiagnięcia celu, ale świadczyło to o olbrzymim braku skuteczności polityki rosyjskiej (Buras, 2008). Rosja dysponuje zasobami soft power, ale brakuje jej zaawansowanej know-how, czy też wyrazistego, przyciagającego projektu kulturowego i przez to ma trudności w zaadaptowaniu się do funkcjonowania w ramach formuły wykorzystania soft power (Podliesnyj, 2008; 205 i n.).

Analizując aktywność Federacji Rosyjskiej na arenie międzynarodowej, a szczególnie na obszarze byłego ZSRR, można odnieść wrażenie, że stara się ona nadrobić opóźnienia w wykorzystaniu miękkich środków oddziaływania. W pierwszej kolejności Rosja musiała wyrzec się paternalizmu i budować dobre relacje z byłymi republikami radzieckimi na nowych, partnerskich zasadach. W swojej aktywności, szczególnie wobec państw „bliskiej zagranicy”, Rosja stosuje cały wachlarz środków, poczynając od politycznych, wojskowych, poprzez gospodarcze i kulturalnoideologiczne.

Inne możliwości w aspekcie gospodarczym daje pomoc rozwojowa. Rosja udziela wsparcia państwom rozwijającym się przeznaczając na pomoc zaledwie $500 \mathrm{mln}$ dolarów rocznie czyli $0,03 \%$ rosyjskiego PKB. Nie jest to dużo, ale Rosja pomocy udziela konsekwentnie, głównie na obszarze WNP. Rosyjska pomoc rozwojowa skierowana jest na realizację konkretnych projektów w zamian za wsparcie ze strony tych państw ${ }^{4}$.

Kościół prawosławny stanowi ważny element kultury, ale również narzędzie sprawowania władzy. Kościół w Rosji rości sobie prawo do bycia jedynym i nieomylnym, dając moralną i duchową legitymizację władzy. Odbiciem tego poglądu jest idea istnienia Moskwy jako Trzeciego Rzymu i dziedzica imperialnej, kulturalnej i duchowej misji starożytnych Rzymian i Bizancjum. Dlatego władza w Rosji często odwołuje się do argumentów religijnych i wspiera się na cerkwi w realizacji swych działań.

${ }^{4}$ OECD Factbook. Economic Environment and Social Statistics 2013-2014, http://www.oecdilibrary.org/economics/data/oecd-factbook-statistic_13_14.pdf (16.03.2015). 
Z myślą o dzieciach i młodzieży, został utworzony program „Witaj Rosjo”, którego celem jest utrzymanie i umocnienie więzi pomiędzy ojczyzną a młodymi rodakami mieszkającymi w państwach ,bliskiej zagranicy”. Umiejętne wykorzystanie języka rosyjskiego w polityce kulturalnej może przynieść wiele korzyści. Promocja rosyjskiej literatury, kinematografii, muzyki, otwieranie szkół nauki języka rosyjskiego oraz instytutów kultury rosyjskiej w poszczególnych państwach mogłoby pomóc w kreowaniu pozytywnego wizerunku Rosji. Poprzez nauczanie języka rosyjskiego można również kreować wizerunek wśród dzieci i młodzieży, tj. tej części społeczeństwa, która w przyszłości będzie podejmowała określone decyzje (Włodkowska-Bagan, 2012: 41).

Na ile język odgrywa rolę w soft power może świadczyć fakt, iż 4 listopada 2006 r., w Dniu Jedności Narodowej, prezydent Władimir Putin ogłosił rok 2007 Rokiem Języka Rosyjskiego. Celem projektu było zwiększenie zainteresowania reszty świata językiem i kulturą Rosji, a także promowanie pozytywnego wizerunku państwa. Zaplanowano wiele wydarzeń kulturalnych, wystaw, prezentacji, konferencji i konkursów. Idąc dalej w określeniu narzędzi kultury, władze ogłosiły plan utworzenia instytucji kulturalnej na wzór zachodnioeuropejski. W dalszej kolejności 21 czerwca 2007 r. ukazem prezydenta FR została ustanowiona Fundacja Rosyjski Świat (ros. Russkij mir), której podstawowym celem jest popularyzacja rosyjskiego języka oraz kultury. Fundacja współpracuje z Ministerstwem spraw zagranicznych i Ministerstwem szkolnictwa, co umożliwiło utworzenie 75 centrów kultury w 39 państwach ${ }^{5}$. Fundacja ma być uzupełnieniem dla działającego wcześniej, od 1996 r. w strukturach państwowych Instytutu Rosyjskiego (Lazari, 1996: 128).

We wrześniu 2008 r. prezydent Miedwiediew podpisał dekret reorganizujący $\mathrm{Fe}$ deralnq Agencję ds. Wspólnoty Niepodległych Państw (Włodkowska, 2006: 54-58). Zmiany te miały na celu centralizację działań pozwalających utrzymać wpływy na obszarze WNP i budowę przyjaznej atmosfery dla realizacji polityczno-gospodarczych interesów Rosji. Nowa instytucja przejęła kompetencje kilku struktur działających na forum międzynarodowym na obszarze kultury. Jej zadaniem było opracowanie spójnej linii programowej szeroko rozumianej współpracy międzynarodowej m.in. poprzez stworzenie planów pomocy dla państw WNP.

Aby skutecznie wykorzystać narzędzia soft power, Rosja musi rozwijać organizacje pozarządowe. Te które powstały po rozpadzie ZSRR, mają swoje oparcie w zagranicznych sieciach przez to podlegają szczególnej uwadze władz. Kreml nie widział w nich wsparcia dla budowania społeczeństwa obywatelskiego, ale raczej przeszkodę dla realizacji własnej polityki. Należało się z nimi rozprawić i powołać nowe, które były by kontrolowane przez państwo (Lucas, 2008: 125).

Jedną z prorządowym fundacji jest utworzona w 2010 r. Fundacja Dyplomacji Publicznej im. A. Gorczakowa oraz Rosyjska Rada Stowarzyszenia Międzynarodowego (RIAC), a w 2012 r. Fundacja Pamięci Historycznej ${ }^{6}$. Fundacja ta określana jest jako organizacja pozarządowa, ale jest to raczej instytucja ściśle związana z rządem. Jej działania są przejawem znacznego wysiłku, jaki czyni władza w celu wykorzystania zasobów rosyjskiego soft power.

\footnotetext{
${ }^{5}$ Ruskij Mir Foundation (2015), http://russkiymir.ru/russkiymir/en/fund/about (16.05.2015).

6 The Alexander Gorczakov Public Diplomacy Fund, http://gorchakovfund.ru (30.03.2017).
} 
Obok rosyjskiej kultury wysokiej istnieje rosyjska kultura popularna, która wywiera również wpływ nie tylko w państwach WNP, ale i w skali międzynarodowej. Wykorzystanie soft power przez FR w polityce wobec państw „bliskiej zagranicy” wiąże się również ze wsparciem dla rosyjskich teatrów i kin. Można dostrzec nacisk kładziony na promocję kina rosyjskiego na całym obszarze Wspólnoty i jego prezentację w ramach organizowanych festiwali filmowych ${ }^{7}$. Prezentacja rosyjskich filmów jest o tyle ważna, że kina państw WNP zalewane są produkcjami zachodnimi. W wielu państwach WNP znaczną liczbą wyświetlanych filmów są obrazy wojenne produkcji rosyjskiej (Łoś, 2017: 265).

Rosja ma również utytułowanych sportowców, którzy są jej wizytówką w świecie (Łoś, 2017: 237). Jest to o tyle ważne, że sport, podobnie jak kino, jest ważnym elementem kultury masowej. Znanymi i podziwianymi rosyjskimi sportowcami są zwłaszcza tenisistki i tenisiści: Jelena Demientiewa, Maria Szarapowa czy Marat Safin. Twarzą kultury masowej stała się często goszcząca na łamach tabloidów Anna Kurnikowa. Powszechnie znana jest także tyczkarka Jelena Isinbajewa czy Swietłana Fieofanowa. Oprócz tego Rosjanie od lat zajmują czołowe miejsca w łyżwiarstwie figurowym i posiadaja jedne z najlepszych lig hokejowych na świecie - Continental Hockey League. Pewną formą wpływów w sferze sportu jest sponsorowanie niektórych drużyn ze Wspólnoty Niepodległych Państw przez firmy rosyjskie. Przykładem jest wspieranie łotewskiej grupy Dinamo Riga przez Itera (dystrybutora gazu). Dodatkowo wielu sportowców woli grać dla rosyjskich grup, gdzie otrzymują lepsze wynagrodzenie.

Równie ważne są imprezy sportowe. Budowaniu wizerunku państwa, a tym samym pośrednio soft power służyły Lekkoatletyczne Mistrzostwa Świata w Moskwie (w 2013 r.), Igrzyska Olimpijskie w Soci (w 2014 r.) i takie mają być mistrzostwa świata w piłce nożnej w $2018 \mathrm{r}$. Igrzyska te mają za zadanie wsparcie wizerunku Rosji w świecie. To może skupić uwagę świata na Rosji, która wykorzysta to marketingowo, co pomoże jej wesprzeć własną opcję polityki zagranicznej. Cieniem na tej sferze soft power kładzie się natomiast afera ze stosowaniem niedozwolonych środków dopingowych.

Edukacja i nauka stanowi ważny element soft power, ponieważ wspomaga formowanie się przyszłych zagranicznych elit ekonomicznych, politycznych i militarnych życzliwych dla państwa, które pomogło je wykształcić. Uczelnie wyższe tworzą część sieci wpływów transnarodowych i mogą podzielać te same wartości (Arafiejev, 2006). Według statystyk UNESCO z roku 2014 w Rosji studiowało ponad 170 tys. zagranicznych studentów, z czego $30 \%$ stanowili studenci z byłych republik ZSRR ${ }^{8}$. Liczba studentów z byłych republik Związku Radzieckiego, uczących się na uczelniach rosyjskich i ich zagranicznych oddziałach i filiach wzrasta. Państwowy Uniwersytet Moskiewski im. Łomonosowa zdecydował się otworzyć swe filie, które znajdują się w Uzbekistanie (w Taszkiencie), Kazachstanie (w Astanie), na Ukrainie (Sewastopol) oraz od 2009 r. w Tadżykistanie (Duszanbe) i Baku (Azerbejdżan). Otwieranie filii Uniwersytetu w państwach „bliskiej zagranicy” pomaga w kształceniu przyszłych kadr i bezpośrednio wpływa na wizerunek Rosji wśród młodych ludzi, tym bardziej że

${ }^{7}$ W 2015 r. odbyła się już 9. edycja festiwalu.

${ }^{8}$ ISCED Fields of Education and Training 2013 (ISCED-F 2013), http://www.uis.unesco.org/ Education/Documents/isced-fields-of-education-training-2013.pdf (12.05.2015). 
Uniwersytet im. Łomonosowa cieszy się dobrą opinią (Włodkowska, 2006: 249-250). Pomimo rozwoju oferty edukacyjnej, Rosja nie jest w stanie konkurować z ofertą najlepiej rozwiniętych państw szeroko pojętego Zachodu.

Wsparciem dla działań rządu są media. Szczególne znaczenie ma Internet, za pomocą którego tworzono sieć, dzięki której wprowadzono do niej fałszywe informacje poprzez zafałszowane strony internetowe. Nieprzypadkowo na początku 2005 r. na czele Departamentu ds. Kontaktów Międzyregionalnych i Kulturalnych z Zagranicą (przy prezydencie FR) stanął Modest Kolerow, którego zadaniem miało być koordynowanie działań z zakresu soft power, w tym związanych z przeciwdziałaniem kolorowym rewolucjom $\mathrm{w}$ państwach WNP m.in. poprzez wprowadzenie w życie rosyjskich teorii wojen informacyjnych (Wojnowski, 2015: 15).

Media są ważnym narzędziem umożliwiającym użycie soft power przez Rosję. Rosyjskie stacje telewizyjne i radiowe, prasa, portale internetowe są ważnym elementem w rozpowszechnianiu informacji w środowiskach, które głównie nastawiają się na kulturę rosyjską. Rosyjskie telewizyjne programy informacyjne mają wymiar polityczny, a jego szczegółowe odniesienia pełne są niejasności, niepewności i półprawd. Rosyjskie media są całkowicie uzależnione od władz, co pozwala na utrzymanie spójności interpretacji zdarzeń. Rosyjską sieć informacyjną tworzy wielki koncern medialny Russia Today (RT), rozgłośnia radiowa Głos Rosji, Wszechrosyjska Państwowa Kompania Telewizyjna i Radiowa, Narodowa Grupa Medialna, Gazprom Media Holding. Platformę medialną tworzy Sputnik. Agencja RIA Novosti pokrywa swym odbiorem 45 państw i nadaje w 14 językach. RT nadaje informacje i komentarze na temat tego co dzieje się na świecie całą dobę. RT jest dostępna w telewizji kablowej, satelitarnej i on-line. Nadaje w językach rosyjskim, angielskim, arabskim i hiszpańskim. Na obszarze WNP programy są nadawane w języku rosyjskim. Od 2007 r. dziennik ,Rosijskaja Gazieta” publikuje dodatkowo miesięcznik w nakładzie ponad 3 mln egzemplarzy. Większość gazet codziennych wydawanych jest też w elektronicznej, angielskiej wersji językowej.

Impuls do wzmocnienia rosyjskiej obecności w mediach społecznościowych dał w lipcu 2012 r. prezydent Władimir Putin podczas spotkania z przedstawicielami dyplomatycznymi Federacji Rosyjskiej. Określił wówczas, że opinia Rosji w wielu kwestiach jest niedostatecznie znana i trzeba ją nieustannie prezentować i wyjaśniać, w tym przy użyciu nowych technologii. W efekcie rosyjskie instytucje oraz urzędnicy i politycy zaczęli intensywniej otwierać konta w mediach społecznościowych, przede wszystkim nierosyjskich. Uruchomiono też nowe wersje stron internetowych rosyjskich urzędów, z bardziej funkcjonalną i przejrzystą szatą graficzną i z wyeksponowanymi odsyłaczami do profili w serwisach społecznościowych (Seib, 2012: 44).

\section{RANKING SOFT POWER}

Możliwości oddziaływania rosyjskiej soft power nie są duże. Wynika to w znacznej mierze w rozumieniu tego zjawiska, co przekłada się na praktykę realizacji miękkiego wpływu. W kategorii dyplomacji najlepiej wypada prezydent Putin, który wzbudza 
uznanie za konsekwencję i styl twardego przywódcy (Roxburgh, 2012). To on otwiera listę najbardziej wpływowych ludzi na świecie. W innych kategoriach jak na skalę państwa wskaźniki lokują Rosję przeciętnie, szczególnie na tle znaczących państw aspirujących do zdobycia lub utrzymania pozycji mocarstwa. Jedynie to co ją wyróżnia, to lepsza pozycja w sferze wykorzystania za granicą instytucji, odpowiedzialnych za promowanie rosyjskiej kultury.

W kategorii społeczno-politycznej Rosja osiagga najgorszą pozycję. Zarówno zakres wolności i swobód, ale również organizacja państwa w Rosji jest fatalna. Takie wskaźniki jak skala wolności oceniane przez Freedomhouse, zakres dostępu do wolnego Internetu, wolność prasy lokuje to państwo daleko poza czołówką światową. W zakresie wolności prasy Rosja notowana jest na 148. miejscu w świecie, co świadczy o ocenie państwa, możliwości krytyki i wolności słowa. Potwierdza to fakt, że reżim w Rosji stworzył demokrację fasadową, która nadto źle wpływa na możliwości sprawnego zarządzania państwem. We wskaźnikach łączących informacje o rządach prawa, swobodach demokratycznych z realizacją przez państwo swych typowych funkcji na 600 punktów uzyskuje 175 i wypada słabiej niż ChRL.

W kategorii spoleczno-gospodarczej ocena Rosji jest nieco lepsza. Wśród wielkich firm jedynie trzy są rozpoznawalne w świecie (spośród stu). Wskaźnik innowacyjności gospodarki lokuje ją na 48. miejscu, a nieco lepszy jest wskaźnik konkurencyjności (42 miejsce). Rosja nie ma również nadzwyczajnych dokonań w zakresie pomocy rozwojowej (21 miejsce z około $700 \mathrm{mln}$ USD rocznej pomocy). Komfort życia (HDI) również nie jest wysoki, ale z uwagi na skalę państwa nie jest to zaskakujące (38. miejsce na świecie). Rosja nie radzi sobie z nierównościami społecznymi, a wskaźnik Giniego lokuje to państwo na 87. miejscu na świecie. Jak na spadkobierców systemu, który miał na celu likwidację nierówności społecznych, to w tej kategorii współczesna Rosja nie może budzić uznania.

Edukacja nie należy do najsilniejszych kategorii rosyjskiej soft power. Państwo to nie ma aż tak silnych uniwersytetów, aczkolwiek lokują się one już w pierwszej 30 . wśród najlepszych. Uniwersytety przyjmują znaczną liczbę studentów obcokrajowców, głównie z obszaru byłego Związku Radzieckiego. Rosja nie budzi uznania skutecznością edukacji na niższych szczeblach, zajmując jedynie 19. miejsce w świecie. Niewielki jest wpływ think tanków, pomimo działania ich znacznej liczby. Liczba Noblistów, którzy otrzymali nagrody w naukach ścisłych nie imponuje, dając im jedynie 9. miejsce w świecie.

Najlepiej Rosja wypada $w$ kategorii kultura popularna $i$ wysoka, aczkolwiek raczej więcej zyskuje na tle kultury zachodniej z uwagi na swoją egzotykę i szczególny zakres duchowości. Rosja wiele zyskuje poprzez upowszechnienie języka rosyjskiego (6. lokata $z$ uwagi na upowszechnienie), robiąc wiele, aby język ten nadal był dominujący na obszarze byłych republikach ZSRR. Lista obiektów na liście UNESCO daje Rosji 6. miejsce, a najchętniej odwiedzane muzea 8. miejsce w świecie. Lista noblistów w zakresie literatury nie imponuje: Rosjanie zdobyli jedynie 3 nagrody dające im dopiero 10. miejsce $\mathrm{w}$ świecie. $\mathrm{W}$ turystyce zajmuje dopiero 9. miejsce, ale już drugie w liczbie uzyskanych medali olimpijskich. Muzyka i film z małymi wyjątkami nie należą do domeny Rosji, podobnie jak piłka nożna, dająca drużynie narodowej 20. miejsce w świecie. 
Tabela 1

Ranking wybranych państw według soft power

\begin{tabular}{|c|l|c|}
\hline Ranking & \multicolumn{1}{|c|}{ Państwo } & Liczba punktów (max 60) \\
\hline 1 & USA & 49,50 \\
\hline 2 & Wielka Brytania & 44,00 \\
\hline 3 & Niemcy & 40,50 \\
\hline 4 & Francja & 39,75 \\
\hline 5 & Szwecja & 30,50 \\
\hline 6 & Holandia & 28,75 \\
\hline $7-8$ & Włochy, Kanada & 27,50 \\
\hline 9 & Dania & 27,00 \\
\hline 10 & Finlandia & 25,75 \\
\hline 11 & Szwajcaria & 25,25 \\
\hline $12-13$ & Austria, Hiszpania & 24,00 \\
\hline 14 & Japonia & 23,50 \\
\hline 15 & ChRL & 23,00 \\
\hline 16 & Australia & 22,50 \\
\hline 17 & Norwegia & 22,25 \\
\hline 18 & Belgia & 21,00 \\
\hline 19 & Polska & 20,00 \\
\hline 20 & Czechy & 17,50 \\
\hline $21-22$ & Rosja, Nowa Zelandia & 16,75 \\
\hline $23-24$ & Irlandia, Korea Pd. & 15,25 \\
\hline 25 & Luksemburg & 14,00 \\
\hline 26 & Brazylia & 11,00 \\
\hline $27-28$ & Islandia, Singapur & 10,75 \\
\hline 29 & Indie & 10,00 \\
\hline 30 & Portugalia & 9,50 \\
\hline
\end{tabular}

Źródło: Łoś, 2016: 243.

Sumując osiagnięcia Rosji w zakresie soft power, zajmuje ona dopiero 21 miejsce. Nie jest to wynik imponujący, ale więcej można powiedzieć o skali miękkiego wpływu po uwzględnieniu różnic w poszczególnych kategoriach.

\section{Wykres 1. Zakres możliwości soft power Rosji według poszczególnych kategorii}

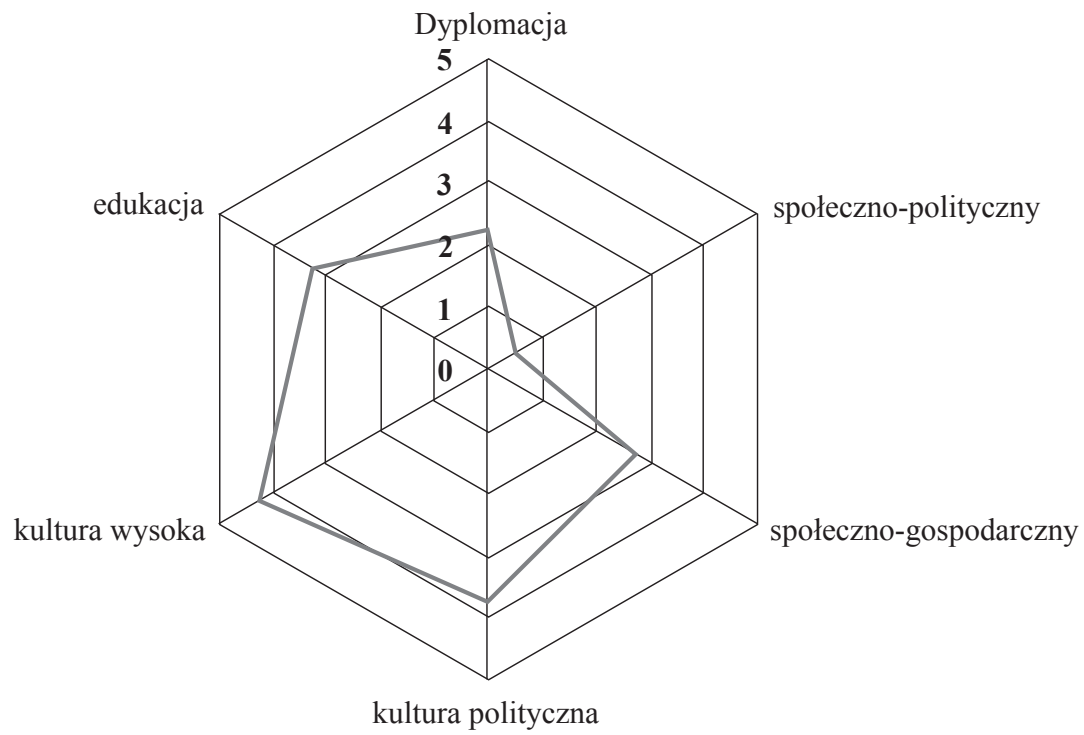

Źródło: Łoś, 2016: 290. Każda kategoria maksymalnie 10 punktów. 
Przedstawiony rosyjski model rozwoju soft power jest asymetryczny. Ten brak harmonii oznacza słabe perspektywy dla dalszego rozwoju miękkiej siły. Oznacza to, że aby doprowadzić do wzrostu soft power, władze rosyjskie będą musiały zużyć wiele środków, które mogą być niewspółmierne z oczekiwanymi rezultatami. Dlatego raczej można się spodziewać, że Rosja będzie bardziej skłonna wykorzystać bardziej twarde narzędzia wpływu, aby osiagnąć zamierzone cele.

\section{$* * *$}

Rosja wiele traci z braku silnego soft power. Trudno jednoznacznie stwierdzić, czy systemowo nie jest w stanie rozwinąć zakresu miękkiego oddziaływania, czy zasoby są zbyt słabe, aby można było tego dokonać. Z pewnością jest to jedno i drugie. Ponadto soft power Rosji obciążony jest dziedzictwem imperializmu i komunizmu. Zarówno imperium carów, jak i radzieckie było bardzo opresyjne, stąd tworzenie i wykorzystywanie soft power jest bardzo trudne. Niemniej Rosja odwołuje się do tradycji słowiańskiej, fascynacji rosyjską duszą i popularnością rosyjskiej kultury na zachodzie. Wykorzystuje również symboliczne określenia, uznając siebie jako depozytariusza dziedzictwa prawosławia i przywódcy świata wschodniego chrześcijaństwa.

W rosyjskiej świadomości ciagle brakuje przekonania o konieczności przestrzegania praw człowieka czy prawa, ale nie jako narzędzi represji czy prześladowań (Broda, 2011: 213). Nawet demonstrowanie siły wobec opozycji sprzyja władzy, ponieważ dzięki temu obywatele czują się spokojniejsi, że władza kontroluje sytuację w państwie (Lucas, 2008). Nawet jeżeli w Rosji są rozbieżności między deklarowanymi wartościami a praktyką ich realizacji, nie stanowi to dla Rosjan przeszkody w ocenie władzy.

Rosji trudno wytworzyć soft power przez zmianę stylu polityki zagranicznej, a tym bardziej by zdobyć serca i umysły ludzkie nie poprzez siłę (szerzej: Michałowska, 1991: 253; Włodkowska, 2008: 65-83). W celu wykorzystania soft power podjęto zauważalne kroki do wypromowania tradycji rosyjskiej za granicą. Te starania odzwierciedlają synergię pomiędzy rządami, półoficjalnymi fundacjami, faworyzowanymi mediami, kościołem i diasporą, aby narzędzia soft power zostały we właściwy sposób spożytkowane w celu utrzymania wpływów na obszarze o szczególnym znaczeniu dla Rosji. Niemniej praktyka polityczna wskazuje, że Rosja bardziej gotowa jest sięgać po narzędzia z kategorii hard power, w razie konieczności rozwiązania konfliktu.

\section{BIBLIOGRAFIA}

Arefjev A. (2006), Skolko Ljudje govorjat i budu govorit po-russki, „Demoskon Weekly”, nr 251-252, http://demoscope.ru/weekly/2006/0251/tema04.php (12.05.2016).

The Art. Newspaper Special Report, Spring/Summer 2014, http://www.museus.gov.br/wp-content/ uploads/2014/04/theArtNewspaper2013_ranking.pdf (2.04.2017).

Avgerinos K. P. (2009), Russia's Public Diplomacy Effort: What the Kremlin is Doing and Why It"s Not Working, ,Journal of Public International Affairs”.

Broda M. (2011), ,Zrozumieć Rosję? O rosyjskiej zagadce-tajemnicy, Łódź. 
Buras P. (2008), Między europeizacja a Gazpromem: Niemcy, Rosja i bezpieczeństwo energetyczne, „Raporty i analizy”, nr 7.

Concept of the Foreign Policy of the Russian Federation 12.02.2013, http://www.mid.ru/brp_4.nsf/0 /76389FEC168189ED44257B2E0039B16D (1.04.2013).

Czajkowski A. (2011), Federacja Rosyjska: przywracanie utraconej wielkości, w: Polityka zagraniczna. Aktorzy, potencjaty, strategie, (red.) T. Łoś-Nowak, Warszawa.

Dolinsky A. (2012), What is Public Diplomacy and Why Russia Needs It, „Russian International Affairs Council”, 16.10.2012, http://rusiancouncil.ru/en/inner/?id_4=913\&from=nov\#top (2.04.2017).

Evens J. (2005), Spinning Russia, „Foreign Policy”, http://demography.ru/xednay/demography/opinions/puting8pr.html (16.04.2015).

ISCED Fields of Education and Training 2013 (2013), http://www.uis.unesco.org/Education/Documents/isced-fields-of-education-training-2013.pdf (12.05.2015).

Grigas A. (2012), Legacies, Coercion and the Soft Power: Russian Influence in the Baltic States, „Briefing Paper. Chatham House”.

Gumilow L. (1996), Od Rusi do Rosji. Szkice z historii etnicznej, Warszawa.

Hill F. (2006), Moscow Discovers Soft Power, „Current History”, No. 10.

Ivakhnyuk I. (2006), Migration In The Cis Region: Common Problems And Mutual Benefits, International Symposium On International Migration And Development Population Division Department of Economic and Social Affairs, United Nations Secretariat, Turin, Italy, 28-30.06.2006, http://www.un.org/esa/population/migration/turin/Symposium_Turin_files/ P10_SYMP_Ivakhniok.pdf. (2.04.2017).

Krasuski J. (2007), Europa między Rosja i światem Islamu, Toruń.

Lazari A. de (1996), Czy Moskwa będzie Trzecim Rzymem, Katowice.

Lucas E. (2008), Nowa zimna wojna. Jak Kreml zagraża Rosji i Zachodowi, Poznań.

Lukyanov F. (2013), Why Russia's Soft Power Is Too Soft, „Russia in Global Affairs”, 1.02.2013, http://eng.globalaffairs.ru/redcol/Why-Russias-Soft-Power-Is-Too-Soft-15845 (2.04.2017).

Matuszewska J. (2010), Trzy światy. Modele polityki zagranicznej Unii Europejskiej, Stanów Zjednoczonych $i$ Rosji, Warszawa.

Miszewski D. (2012), Percepcja wojny sierpniowej w kulturze masowej, w: Konflikt Kaukaski, (red.) R. Potocki, M. Domagała, P. Sieradzan, Warszawa.

Nye J. S. (1991), Bound to Lead: the Changing Nature of American Power, New York.

Nye J. S. (2002), The Paradox of American Power, New York.

Nye J. S. (2005), Soft Power: The Means to Success In World Politics, New York.

Nye J. S. (2007), Soft Power. Jak osiagnać sukces w polityce światowej, Warszawa.

Nye J. S. (2011), The Future of Power, New York.

Nye J. S. (2013), What China and Russia Don't Get About Soft Power, „Foreign Policy”, 29.04.2013, http://www.foreignpolicy.com/articles/2013/04/29/what_china_and_russia_don_t_get_ about_soft_power (2.04.2017).

Podliesnyj P. T. (2004), Politika SSZA w mieniajuszczemsjamirie, Moskwa.

Potocki R. (2009), Wojna Sierpniowa, Warszawa.

OECD Factbook. Economic Environment and Social Statistics 2013-2014 (2014), http://www.oecdilibrary.org/economics/data/oecd-factbook-statistic_13_14.pdf (16.03.2015).

O russkom jazykie, http://bd.fom.ru/report/cat/cult/lang_1/du06031008 (2.04.2017).

O russkomjazykie, http://bd.fom.ru/report/cat/cult/lang_1/k020306 (2.04.2017). 
Pastukhov V. (2010), Ukraina do lzhnakakmozhnobystree preodolete po khuidentifikatsii sebya, http://polit.ua/articles/2010/11/26/pastoukhov.html (12.09.2016).

Rodkiewicz W. (2013), Koncepcja polityki zagranicznej Federacji Rosyjskiej, „Tydzień na Wschodzie", 20.02.2013, http://www.osw.waw.pl/pl/publikacje/tydzien-na-wschodzie/2013-02-20/ koncepcja-polityki-zagranicznej-federacji-rosyjskiej (2.04.2017).

Rossija i strany SNG, Federalnaja służba gosudarstwiennojstatistiki, 2007http://www.gks.ru/bgd/ regl/b06_05/IssWWW.exe/Stg/d010/6-03.htm (2.04.2017).

Roxburgh A. (2012), The Strongman: Vladimir Putin and the Struggle for Russia, London.

Sherr J. (2013), Hard Diplomacy and Soft Coercion, Russia Influence Abroad, Chatham House, Washington.

Seib P. (2012), Real-Time Diplomacy: Politics and Power in the Social media Era, New York.

Włodkowska-Bagan A. (2012), Soft Power w polityce zagranicznej Federacji Rosyjskiej wobec państw „, bliskiej zagranicy”, „E-Politikon”, nr 3, http://yadda.icm.edu.pl/yadda/element/ bwmeta1.element.desklight-7b8cd287-f391-4b49-bed00f6e14d99e74 (2.04.2017).

Włodkowska A. (2006), Polityka Federacji Rosyjskiej na obszarze WNP, Toruń.

Włodkowska A. (2008), Problemy rosyjskiej dominacji na obszarze WNP, „Rocznik Instytutu Europy Środkowo-wschodniej", nr 6.

Wojnowski M. (2015), Zarzadzanie refleksyjne jako paradygmat rosyjskich operacji informacyjnopsychologicznych w XXI wieku, „Przegląd Bezpieczeństwa Wewnętrznego”, nr 12.

Wyciszkiewicz E. (2003), Współczesna Rosja wobec Zachodu, Łódź.

Yeleyko I. (2007), Specyfika migracji zarobkowej ludności na Ukrainie, „Nierówności społeczne a wzrost gospodarczy", zeszyt $\mathrm{nr}$ 11, http://www.ur.edu.pl/pliki/Zeszyt11/30.pdf (2.04.2017).

\title{
STRESZCZENIE
}

Rosja zawsze była państwem, które dążyło, aby być mocarstwem. Nawet jeżeli straciło znaczenie po rozpadzie ZSRR, to chęć powrotu jako twórcy porządku międzynarodowego, wymusza wypracowanie nowej strategii, która przewiduje użycie środków soft power. Stanowi to pewną przeszkodę dla Rosji, która tradycyjnie przygotowana jest do użycia sił zbrojnych czy presji ekonomicznej. Dużo gorzej jest z wykorzystaniem wartości, które w zamierzeniach Moskwy powinny być różne od Zachodu. Wynikało to z tego, że Rosja stara się stworzyć konkurencyjny do zachodu projekt soft power. Rosja stara się dobrze wykorzystać swoją dyplomację, w tym cyfrową, umiejętnie jej używając nawet jako narzędzi propagandy czy walki w cyberprzestrzeni.

Słowa kluczowe: rosyjska soft power, zasoby, dyplomacja publiczna

\section{RUSSIAN SOFT POWER}

\begin{abstract}
Russia has always been a country seeking the Great Power status. Even though it lost its importance after the collapse of the Soviet Union, the desire to return to the role of the creator of international order force it to introduce new strategy that will implement soft power resources.
\end{abstract}


This represents a certain obstacle for Russia, which traditionally is accustomed to hard power resources like economic pressure or the use of armed forces. Culture is Russia's soft power resource that is significant. Values can be more problematic for Russia, because in Moscow's intentions they should be different from the Western values. Russia is trying to create an alternative soft power project, competitive to that of the West. Russia is trying to make good use of its diplomacy, including digital diplomacy, in order to show the use of its hard power to be seen as soft.

Keywords: Russian soft power resources, public diplomacy 
